\title{
Greenhouse gas emissions from Indian rice fields: calibration and upscaling using the DNDC model
}

\author{
H. Pathak ${ }^{1, *}$, C. $\mathbf{L i}^{2}$, and R. Wassmann ${ }^{3}$ \\ ${ }^{1}$ Unit of Simulation and Informatics, Indian Agricultural Research Institute, New Delhi, India \\ ${ }^{2}$ Institute for the Study of Earth, Oceans, and Space, University of New Hampshire, Durham, New Hampshire, USA \\ ${ }^{3}$ Institute for Meteorology and Climate Research (IMK-IFU), Forschungszentrum Karlsruhe, Garmisch-Partenkirchen, \\ Germany \\ * currently at IMK-IFU, Germany
}

Received: 1 December 2004 - Published in Biogeosciences Discussions: 20 January 2005

Revised: 6 April 2005 - Accepted: 10 May 2005 - Published: 27 May 2005

\begin{abstract}
The Denitrification and Decomposition (DNDC) model was evaluated for its ability to simulate methane $\left(\mathrm{CH}_{4}\right)$, nitrous oxide $\left(\mathrm{N}_{2} \mathrm{O}\right)$ and carbon dioxide $\left(\mathrm{CO}_{2}\right)$ emissions from Indian rice fields with various management practices. The model was calibrated and validated for field experiments in New Delhi, India. The observed yield, $\mathrm{N}$ uptake and greenhouse gas (GHG) emissions were in good agreement with the values predicted by the model. The model was then applied for estimation of GHG emissions from rice fields in India using a newly compiled soil/climate/land use database. Continuous flooding of rice fields ( 42.25 million ha) resulted in annual net emissions of 1.07-1.10, 0.04-0.05 and 21.16-60.96 Tg of $\mathrm{CH}_{4}-\mathrm{C}, \mathrm{N}_{2} \mathrm{O}-\mathrm{N}$ and $\mathrm{CO}_{2}-\mathrm{C}$, respectively, with a cumulated global warming potential (GWP) of 130.93-272.83 $\mathrm{Tg} \mathrm{CO} 2$ equivalent. Intermittent flooding of rice fields reduced annual net emissions to $0.12-0.13$ $\mathrm{Tg} \mathrm{CH}_{4}-\mathrm{C}$ and $16.66-48.80 \mathrm{Tg} \mathrm{CO}_{2}-\mathrm{C}$ while $\mathrm{N}_{2} \mathrm{O}$ emission increased to $0.05-0.06 \mathrm{Tg} \mathrm{N} \mathrm{N}_{2} \mathrm{O}-\mathrm{N}$. The GWP, however, reduced to 91.73-211.80 $\mathrm{Tg} \mathrm{CO}_{2}$ equivalent. The study suggested that the model could be applied for estimating the GHG emissions and the influences of agronomic management, soil and climatic parameters on the GHG emissions from rice fields in India.
\end{abstract}

\section{Introduction}

The production of rice in South Asia, including India, has increased markedly with the introduction and widespread adoption of modern crop production technologies such as early maturing and $\mathrm{N}$ responsive semi-dwarf cultivars; high

Correspondence to: H. Pathak

(hpathak_cass@yahoo.com) use of inorganic fertilizers, especially $\mathrm{N}$ fertilizers, and pesticides; and the expansion of irrigation facilities. Most of the rice in monsoonal Asia is grown as a transplanted crop in wet season from July to October (known as kharif season in India), where fields are flooded before planting and the soil is puddled to reduce percolation. The chemical environment of reduced soil and the extremely limited $\mathrm{O}_{2}$ supply in the soil-floodwater system has a large influence on carbon (C) and nitrogen $(\mathrm{N})$ dynamics of irrigated rice systems.

Carbon dioxide $\left(\mathrm{CO}_{2}\right)$, methane $\left(\mathrm{CH}_{4}\right)$ and nitrous oxide $\left(\mathrm{N}_{2} \mathrm{O}\right)$ are the key greenhouse gases $(\mathrm{GHG})$ that contribute towards the global warming at 60,15 and $5 \%$, respectively (Watson et al., 1996). Concentrations of these gases in the atmosphere are increasing at $0.4,3.0$ and $0.22 \%$ per year, respectively (Battle et al., 1996). Apart from causing global warming $\mathrm{N}_{2} \mathrm{O}$ is also responsible for the destruction of the stratospheric ozone (Rodhe, 1990; Li et al., 2004). Quantification of GHG emissions from soil is needed for global modelling studies in the context of ecosystem modification and climate change (Li et al., 1997). Global and regional estimates of GHG emission from rice paddy fields vary greatly with the assumptions made on the importance of different factors affecting the emissions. Only a few studies (Bachelet and Neue, 1993; Mathews et al., 2000a, b, c; Yan et al., 2003; $\mathrm{Li}$ et al., 2004) have attempted to calculate detailed regional GHG emissions.

Several models have been developed in recent years to predict emissions of $\mathrm{CH}_{4}$ and $\mathrm{N}_{2} \mathrm{O}$ from agricultural fields. Early models used regression relationships between rates of emissions and either the crop biomass (Sinha, 1995; Kern et al., 1997) or grain yield (Anastasi et al., 1992). These relationships were based on the assumption that higher the biomass production of the crop, the more substrate would

(C) 2005 Author(s). This work is licensed under a Creative Commons License. 
be available for $\mathrm{CH}_{4}$ production, either from increased crop residues or from higher rates of rhizo-deposition. Cao et al. (1995) presented a more differentiated approach describing $\mathrm{CH}_{4}$ production and oxidation in rice fields. In this model, soil organic carbon (SOC) was assumed to be partitioned between three main pools based on their rates of decomposition. The seasonal pattern of redox potential (Eh) was required as an input in the model. Huang et al. (1998) used two pools in their model to represent soil organic matter, with different potential decomposition rates for each; these were modified by multipliers representing the influence of soil texture and temperature. As with the Cao et al. (1995) model, $\mathrm{CH}_{4}$ production was affected directly by soil $\mathrm{Eh}$, although this was simulated rather than used as a model input. $\mathrm{Lu}$ et al. (2000) developed a model for $\mathrm{CH}_{4}$ production derived from incubation studies. Matthews et al. (2000a, b, c) developed MERES (Methane Emission in Rice EcoSystems) model for simulating $\mathrm{CH}_{4}$ emissions from rice fields. The model was based on CERES-Rice model but did not simulate $\mathrm{N}_{2} \mathrm{O}$ or $\mathrm{CO}_{2}$ emissions. Other models, however, do simulate the entire set of GHG, for example, CENTURY (Parton, 1996), DNDC ( $\mathrm{Li}, 2000)$ and InfoCrop (Aggarwal et al., 2004), but are not yet at a stage where their predictive ability is satisfactory. Moreover, the models have not been frequently used for tropical regions.

The objectives of the present study were to evaluate the DNDC model for its ability to simulate (1) GHG emissions and global warming potential (GWP) of rice fields with different management practices and (2) GHG emissions from the various rice-growing regions of India.

\section{Materials and methods}

\subsection{Description of the DNDC model}

The Denitrification-Decomposition (DNDC) model ( $\mathrm{Li}$, 2000 ) is a generic model of $\mathrm{C}$ and $\mathrm{N}$ biogeochemistry in agricultural ecosystems. The model simulates $\mathrm{C}$ and $\mathrm{N}$ cycling in agro-ecosystems at a daily or sub daily time step. It consists of 6 interacting submodels: soil climate, plant growth, decomposition, nitrification, denitrification and fermentation (Li et al., 1997). In DNDC, SOC resides in 4 major pools: plant residue (i.e. litter), microbial biomass, humads (or active humus), and passive humus. Each pool consists of 2 or 3 sub-pools with different specific decomposition rates. The soil climate submodel simulates soil temperature and moisture profiles based on soil physical properties, daily weather and plant water use. The plant growth submodel calculates daily water and $\mathrm{N}$ uptake by vegetation, root respiration, and plant growth and partitioning of biomass into grain, stalk and roots. The decomposition submodel simulates daily decomposition, nitrification, ammonia volatilization and $\mathrm{CO}_{2}$ production by soil microbes. The submodel calculates turnover rates of soil organic matter at a daily time step ( $\mathrm{Li}$ et al.,
1994). The nitrification submodel tracks growth of nitrifiers and turnover of ammonium to nitrate. The denitrification submodel operates at an hourly time step to simulate denitrification and the production of nitric oxide (NO), $\mathrm{N}_{2} \mathrm{O}$, and dinitrogen $\left(\mathrm{N}_{2}\right)$. The fermentation submodel simulates $\mathrm{CH}_{4}$ production and oxidation under anaerobic conditions. The DNDC model simulates $\mathrm{CH}_{4}$ and $\mathrm{N}_{2} \mathrm{O}$ production/consumption through a kinetic scheme "anaerobic balloon" (Li, 2000; Stange et al., 2000; Li et al., 2004). The size of the anaerobic balloon sitting in a soil layer is defined to be the anaerobic volumetric fraction, which is quantified by the soil redox potential (Eh). In DNDC, nitrification and denitrification, or $\mathrm{CH}_{4}$ production and oxidation, occur in a soil simultaneously. The $\mathrm{N}_{2} \mathrm{O}$ produced through nitrification outside of the balloon can diffuse into the balloon to participate in denitrification, and can be further reduced to $\mathrm{N}_{2}$. The same is true for $\mathrm{CH}_{4}$. The $\mathrm{CH}_{4}$ produced within the balloon can diffuse into outside of the balloon to be oxidized. In general, nitrification and denitrification, or $\mathrm{CH}_{4}$ production and oxidation, are both modeled in DNDC. The model tracks soil Eh evolution by simulating reductions of nitrate, $\mathrm{Mn}, \mathrm{Fe}$, and sulfate. Initial concentrations of the substrates can be defined by users, although DNDC provides default values of their geochemical background. The model has been validated against a number of field data sets observed in China, the USA, Japan, and Thailand and widely used over the last 10 years by many researchers (Brown et al., 2002; Butterbach-Bahl et al., 2004; Cai et al. 2003; Li et al., 1997; 2000; 2004; Smith et al., 2002; 2004). Simulated results showed that DNDC was able to simulate the basic patterns of $\mathrm{NO}, \mathrm{N}_{2} \mathrm{O}, \mathrm{CH}_{4}$ and $\mathrm{NH}_{3}$ fluxes simultaneously ( $\left.\mathrm{Li}, 2000\right)$. This feature could be valuable in assessing the net effect of the changing climate or alternative agricultural management on either the atmosphere or agriculture.

Recently the DNDC model has been modified for predicting GHG emissions from paddy rice ecosystems ( $\mathrm{Li}$ et al., 2004). The majority of the modifications focused on simulations of anaerobic biogeochemistry and rice growth as well as the parameterization of paddy rice management. The modified model was tested for its sensitivities to management alternatives and variations in climate and soil properties. When estimating GHG emissions under specific management conditions at regional scale, the spatial heterogeneity of soil properties (e.g. texture, SOC content, $\mathrm{pH}$ ) are the major sources of uncertainty. An approach, the most sensitive factor (MSF) method, was developed for DNDC to reduce the magnitude of the uncertainty (Li et al., 2004). The modified DNDC model was used for estimating emissions of $\mathrm{CO}_{2}, \mathrm{CH}_{4}$, and $\mathrm{N}_{2} \mathrm{O}$ from all of the rice paddies in China with two different water management practices, i.e. continuous flooding and midseason drainage that were the dominant practices before 1980 and in 2000, respectively ( $\mathrm{Li}$ et al., 2004). In the present study this modified model was further refined to simulate emissions of $\mathrm{CO}_{2}, \mathrm{CH}_{4}$, and $\mathrm{N}_{2} \mathrm{O}$ under the conditions found in rice paddies of India. 


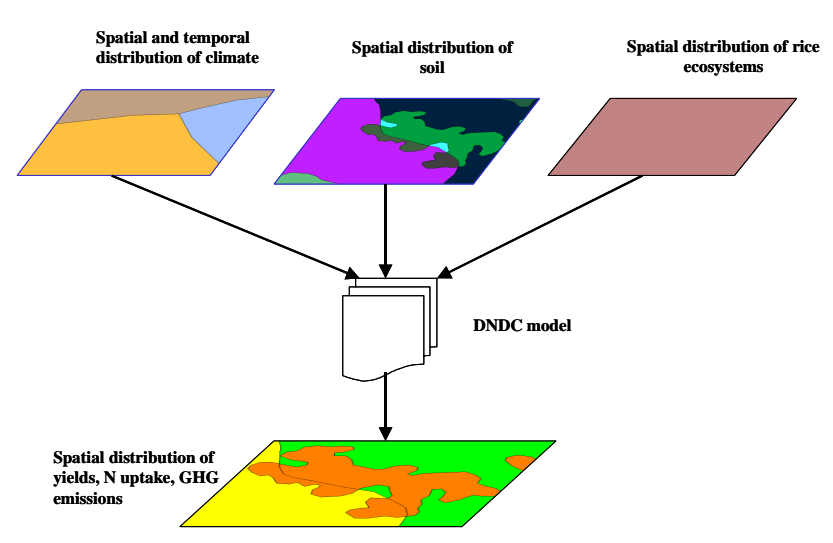

Fig. 1. Approaches for the upscaling of greenhouse gas emission from rice fields in India using the DNDC model.

\subsection{Model modification}

Modifications were made for the DNDC model to improve its performance in simulating crop yield and $\mathrm{CH}_{4}$ emissions for Indian rice fields. Most of the crop physiological and phenological parameters set in the DNDC model were originally calibrated against datasets observed in the US, China or other temperate regions. Discrepancies appeared when the model was applied for the rice crops in India. Modifications were made with the accumulative thermal degree-days as well as the growth rates of vegetative and reproductive stages to adjust the rice-growing season. These modifications have improved the model's ability to predict rice crop yields in India.

Originally the $\mathrm{CH}_{4}$ fluxes simulated by the model were higher than the measured fluxes in some rice paddies in India (Pathak et al., 2003). Test runs for the sites where the low $\mathrm{CH}_{4}$ fluxes were not captured by DNDC indicated that these sites had relatively high leaking rates. The leaking processes embedded in the model were modified to let the process lead to not only water but also substrates e.g. dissolved organic carbon (DOC) and nitrate loss from the paddy soils. This modification has substantially decreased $\mathrm{CH}_{4}$ emissions from the sites with high leaking rates. After modifications, all of the field cases were re-run with the modified DNDC. The results indicated that the modifications did not alter the original results at all for the soils with low or moderate leaking rates, and improved the simulations for the high leaking soils. However, the leached DOC may be mineralised in the aquifer and could play a certain role in GHG production in the aquatic systems. But the current version of DNDC does not track the fate of DOC in underground water or streams and is not capable to simulate aquatic biogeochemistry. Its capacity of predictions is limited to the plant-soil system within the field scale of cropland. A graphic interface was built in the DNDC model to browse the regional database as well as to map the modeled results e.g. crop yield, $\mathrm{C}$ sequestration, $\mathrm{CH}_{4} \mathrm{~N}_{2} \mathrm{O}$, or $\mathrm{CO}_{2}$ emissions for India.

\subsection{Model calibration}

Two field experiments were used for the calibration of the model (Pathak et al., 2002, 2003). The experiments were conducted at the experimental farm of the Indian Agricultural Research Institute, New Delhi, India. The site is located at $28^{\circ} 40^{\prime} \mathrm{N}$ and $77^{\circ} 12^{\prime} \mathrm{E}$, subtropical, semi-arid, with annual rainfall of $750 \mathrm{~mm}$. The mean maximum and minimum temperatures from July to October (rice season) are 35 and $18^{\circ} \mathrm{C}$, respectively. The alluvial soil of the experimental site was sandy loam in texture and has organic carbon, total $\mathrm{N}$, Olsen $\mathrm{P}$, and ammonium acetate extractable $\mathrm{K}$ contents of $4.5 \mathrm{~g} \mathrm{~kg}^{-1}, 0.30 \mathrm{~g} \mathrm{~kg}^{-1}, 0.007 \mathrm{~g} \mathrm{~kg}^{-1}$, and $0.13 \mathrm{~g} \mathrm{~kg}^{-1}$, respectively. The soils are well drained with the groundwater table at 6.6 and $10.0 \mathrm{~m}$ deep during the rainy and summer seasons, respectively.

The experiments included treatments varying in $\mathrm{N}$ sources and water management in plots of $6 \mathrm{~m}$ long and $5 \mathrm{~m}$ wide. Three, 30 days old rice seedlings (cultivar Pusa 44) were transplanted at $20 \mathrm{~cm}$ (row to row) by $15 \mathrm{~cm}$ (hill to hill) spacing on 15 July 1999. Emissions of $\mathrm{CH}_{4}$ and $\mathrm{N}_{2} \mathrm{O}$ were measured frequently from the plots following the standard methodologies (Pathak et al., 2002; 2003). Total dry matter, grain yield and $\mathrm{N}$ uptake were measured at maturity.

The genetic coefficients for rice cultivar, used as model inputs to describe crop phenology in response to temperature and photoperiod, were estimated from independent treatments with water and $\mathrm{N}$ non-limiting by adjusting the coefficients until close matches were achieved between simulated and observed phenology and yield. Total thermal time requirement for rice cultivar found to be $2250^{\circ} \mathrm{C}$. Rate constants of crop development in vegetative and reproductive stages were 0.015 and $0.044 \mathrm{~d}^{-1}$, respectively.

\subsection{Sensitivity analyses}

Model sensitivity was evaluated for changes in the application rates of $\mathrm{N}$ fertilizer and irrigation on rice yields and GHG emissions using the baseline data (weather, soil, cultivar, location and other inputs) of the experiment.

\subsection{Global warming potential}

Global warming potential (GWP) is an index defined as the cumulative radiative forcing between the present and some chosen later time "horizon" caused by a unit mass of gas emitted now. It is used to compare the effectiveness of each GHG to trap heat in the atmosphere relative to some standard gas, by convention $\mathrm{CO}_{2}$. The GWP for $\mathrm{CH}_{4}$ (based on a 100 -year time horizon) is 21 , while that for $\mathrm{N}_{2} \mathrm{O}$, it is 310 when GWP value for $\mathrm{CO}_{2}$ is taken as 1 . The GWP of different treatments were calculated using the following equation (Watson et al., 1996).

$\mathrm{GWP}=\mathrm{CO}_{2}$ emission $+\mathrm{CH}_{4}$ emission $* 21+\mathrm{N}_{2} \mathrm{O}$ emission $* 310$ 
Table 1. Observed and simulated records on harvested yield and biomass as well as N uptake and GHG emission from rice fields in Northern India applied with $120 \mathrm{~kg}_{\text {urea }} \mathrm{N} \mathrm{ha}^{-1}$.

\begin{tabular}{llll}
\hline \multicolumn{1}{c}{ Parameters } & $\begin{array}{l}\text { Observed } \\
\left(\mathrm{kg} \mathrm{ha}^{-1}\right)\end{array}$ & $\begin{array}{l}\text { Simulated } \\
\left(\mathrm{kg} \mathrm{ha}^{-1}\right)\end{array}$ & $\begin{array}{l}\text { Deviation } \\
(\%)\end{array}$ \\
\hline Grain yield $\left(\mathrm{kg} \mathrm{ha}^{-1}\right)$ & 6800 & 6815 & 0.2 \\
Total biomass $\left(\mathrm{kg} \mathrm{ha}^{-1}\right)$ & 17436 & 17718 & 1.6 \\
Crop N uptake $\left(\mathrm{kg} \mathrm{N} \mathrm{ha}^{-1}\right)$ & 126 & 128 & 1.6 \\
Seasonal $\mathrm{CH}_{4}$ emission $\left(\mathrm{kg} \mathrm{CH}_{4}-\mathrm{C} \mathrm{ha}^{-1}\right)$ & 28 & 27 & 3.6 \\
Seasonal $\mathrm{N}_{2} \mathrm{O}$ emission $\left(\mathrm{kg} \mathrm{N}_{2} \mathrm{O}-\mathrm{N} \mathrm{ha}^{-1}\right)$ & 0.74 & 0.69 & 6.8 \\
\hline
\end{tabular}

2.6 Upscaling GHG emissions from rice growing areas in India

The approach for the upscaling GHG emissions using the DNDC model and geographical information system (GIS) are depicted in Fig. 1. The required input parameters of the DNDC model consisting of daily meteorological data (maximum and minimum temperatures, precipitation and solar radiation), soil properties (SOC, clay contents, $\mathrm{pH}$ and bulk density) and area under different rice ecosystems (irrigated lowland, rainfed lowland, rainfed upland and deepwater) were compiled in a GIS database. India is divided into several states and the states are further divided into different administrative boundaries called districts. It was decided that since much of the statistical data was district based that districts should be chosen as the basic geographic unit of the database to maintain the maximum accuracy of the original data sets. The meteorological data was obtained from National Climatic Data Center, USA and consisted of daily records of more than 110 climatic stations across India. Soil properties were compiled from NBSS and LUP (1998), Velayutham and Bhattacharya (2000) and Kalra (2004, personal communication). Field area under the four major rice ecosystems in the different districts of the country was compiled from published data (FAI, 2000; FAO, 2000; Yadav and Subba Rao, 2001; Bhatia et al., 2004). For irrigated lowland and rainfed lowland rice systems simulations were done for two irrigation practices: 1) continuous flooding and 2) intermittently flooding during the cropping season. In both the cases $120 \mathrm{~kg} \mathrm{~N} \mathrm{ha}^{-1}$ per season was applied through urea, broadcast at 3 splits i.e. $1 / 2$ at 1 day after transplanting (DAT), $1 / 4$ at 30 DAT and $1 / 4$ at 55 DAT. In case of the rainfed upland system no irrigation was applied and the fields were never flooded while for the deepwater rice system fields were kept continuously submerged with water. For the latter two systems $64 \mathrm{~kg} \mathrm{~N} \mathrm{ha}^{-1}$ was applied through urea, broadcast at 2 equal splits at 1 and 30 DAT, respectively as per the practice commonly followed by the farmers. For all the rice systems field was ploughed 3 times with moldboard plough before rice transplanting. The model calculated annual $\mathrm{CO}_{2}, \mathrm{CH}_{4}$, and $\mathrm{N}_{2} \mathrm{O}$ fluxes from each rice ecosystem for two scenarios:
(1) minimum emission and (2) maximum emission. The scenario for minimum emission includes the minimum values of SOC, $\mathrm{pH}$ and bulk density and the maximum value of clay content of soil while the scenario for maximum emission includes the maximum values of SOC, $\mathrm{pH}$ and bulk density and the minimum value of clay content of soil.

\section{Results and discussion}

\subsection{Evaluation of the model}

Predicted grain and biomass yields and $\mathrm{N}$ uptake by rice agreed well with the observed values (Table 1). The observed emission of $\mathrm{CH}_{4}$ during the growing season was $28.00 \mathrm{~kg} \mathrm{ha}^{-1}$, while the simulated emission was $27.00 \mathrm{~kg} \mathrm{ha}^{-1}$. Emission of $\mathrm{N}_{2} \mathrm{O}$ was $0.74 \mathrm{~kg} \mathrm{~N}_{2} \mathrm{O}-\mathrm{N} \mathrm{ha}^{-1}$ while the simulated value was $0.69 \mathrm{~kg} \mathrm{~N}_{2} \mathrm{O}-\mathrm{N} \mathrm{ha}^{-1}$. In all the cases the deviation of the simulated value from the observed value was less than $5 \%$ except in case of $\mathrm{N}_{2} \mathrm{O}$ emission when the deviation was $6.8 \%$ (Table 1). Thus the model was able to simulate the annual emission satisfactorily. The measured daily $\mathrm{CH}_{4}$ fluxes varied from almost nil to $2.50 \mathrm{~kg} \mathrm{ha}^{-1} \mathrm{~d}^{-1}$ at different times. This was due to changes in water management. But the simulated daily fluxes varied between nil to $3.20 \mathrm{~kg} \mathrm{ha}^{-1} \mathrm{~d}^{-1}$. This could have been due to inadequate characterization of the initial SOC in the field and the possibility of unsatisfactory simulation of soil Eh by the model. The later is the result of a large number of interactions between physical, chemical and biological properties of soil and water fluxes. Works are in progress to fine-tune the model to improve the prediction of the daily flux events.

\subsection{Sensitivity analysis}

Different application rates of $\mathrm{N}$ fertilizer significantly influenced the simulated yield, $\mathrm{N}$ uptake and emissions of GHG from soil (Table 2). Grain yield of rice as well as $\mathrm{N}$ uptake increased with application rate up to $300 \mathrm{~kg} \mathrm{~N} \mathrm{ha}^{-1}$, but with smaller increases at rates above $180 \mathrm{~kg} \mathrm{~N} \mathrm{ha}^{-1}$. Emissions of $\mathrm{CO}_{2}$ and $\mathrm{CH}_{4}$ increased considerably with $\mathrm{N}$ application because of more root growth of rice generating more amounts 
Table 2. Sensitivity analysis for different rates of $\mathrm{N}$ application, water regimes and manure application affecting simulated rice yields, $\mathrm{N}$ uptake and annual GHG emissions.

\begin{tabular}{|c|c|c|c|c|c|c|}
\hline $\begin{array}{l}\text { Urea N } \\
\left(\mathrm{kg} \mathrm{ha}^{-1}\right)\end{array}$ & Water regime $^{a}$ & $\begin{array}{l}\text { Grain yield } \\
\left(\mathrm{kg} \mathrm{ha}^{-1}\right)\end{array}$ & $\begin{array}{l}\text { N uptake } \\
\left(\mathrm{kg} \mathrm{N} \mathrm{ha}^{-1}\right)\end{array}$ & $\begin{array}{l}\mathrm{CO}_{2} \text { emission } \\
\left(\mathrm{kg} \mathrm{C} \mathrm{ha}^{-1}\right)\end{array}$ & $\begin{array}{l}\mathrm{CH}_{4} \text { emission } \\
\left(\mathrm{kg} \mathrm{C} \mathrm{ha}^{-1}\right)\end{array}$ & $\begin{array}{l}\mathrm{N}_{2} \mathrm{O} \text { emission } \\
\left(\mathrm{kg} \mathrm{N} \mathrm{ha}^{-1}\right)\end{array}$ \\
\hline 0 & $\mathrm{CF}$ & 1775 & 33 & 712 & 40 & 1.85 \\
\hline 120 & $\mathrm{CF}$ & 7320 & 137 & 760 & 96 & 1.85 \\
\hline 180 & $\mathrm{CF}$ & 9015 & 169 & 771 & 101 & 1.85 \\
\hline 240 & $\mathrm{CF}$ & 10015 & 188 & 774 & 103 & 1.89 \\
\hline 120 & $1 \mathrm{MD}$ & 7210 & 135 & 690 & 66 & 1.93 \\
\hline 120 & $2 \mathrm{MD}$ & 7075 & 133 & 617 & 42 & 1.96 \\
\hline
\end{tabular}

${ }^{a} \mathrm{CF}=$ continuous flooding; $1 \mathrm{MD}$ and $2 \mathrm{MD}=1$ and 2 midseason drainages, respectively.

${ }^{b}$ plus $60 \mathrm{~kg} \mathrm{~N}$ from farmyard manure.

of root exudates and debris, which supplied $\mathrm{C}$ for the heterotrophic microbes. Further increase in $\mathrm{N}$ levels i.e. from 180 to $300 \mathrm{~kg} \mathrm{~N} \mathrm{ha}^{-1}$ had little influence on the emissions because of their limited additional influence over $120 \mathrm{~kg} \mathrm{~N}^{-1}$ on rice growth. Emission of $\mathrm{N}_{2} \mathrm{O}$, however, remained unchanged up to $180 \mathrm{~kg} \mathrm{Nha}^{-1}$. As the fields were continuously flooded keeping them anaerobic throughout the growing period, the process of nitrification producing $\mathrm{NO}_{3}^{-}$from $\mathrm{NH}_{4}^{+}$was stopped, and denitrification was also inhibited because of non-availability of substrate $\left(\mathrm{NO}_{3}^{-}\right)$for this process. These two processes i.e. nitrification and denitrification are mainly responsible for the formation of $\mathrm{N}_{2} \mathrm{O}$ in soil (Duxbury et al., 1982). However, application of more than $180 \mathrm{~kg} \mathrm{~N} \mathrm{ha}^{-1}$ through urea increased $\mathrm{N}_{2} \mathrm{O}$ emission because larger fluxes of $\mathrm{NH}_{4}^{+}-\mathrm{N}$.

Substituting $60 \mathrm{~kg} \mathrm{Nha}^{-1}$ urea $\mathrm{N}$ with farmyard manure (FYM) reduced grain yield and $\mathrm{N}$ uptake by rice but increased GHG emissions as compared to application of $120 \mathrm{~kg} \mathrm{Nha}^{-1}$ through urea alone. Addition of organic $\mathrm{C}$ through FYM was responsible for such increase in the GHG emissions (Adhya et al., 2000; Pathak et al., 2002).

Water management also influenced the simulated yield, $\mathrm{N}$ uptake and emissions of GHG from soil (Table 2). Treatments with continuous flooding gave higher yield, $\mathrm{N}$ uptake, and $\mathrm{CH}_{4}$ and $\mathrm{CO}_{2}$ emissions compared to the midseason drainage treatments. Emission of $\mathrm{CH}_{4}$ reduced by $31 \%$ and $54 \%$ with 1 and 2 midseason drainages of 10 days each compared to that under continuously flooded soil. Nitrous oxide emission, on the other hand, increased marginally with midseason drainage, which resulted in aerobic condition of soil with enhanced nitrification forming $\mathrm{N}_{2} \mathrm{O}$ and $\mathrm{NO}_{3}^{-}-\mathrm{N}$. It also enhanced denitrification by supplying the substrate $\left(\mathrm{NO}_{3}^{-}\right)$ for the denitrifiers resulting in more $\mathrm{N}_{2} \mathrm{O}$ emission when the field was reflooded (Aulakh et al., 1992).

The $\mathrm{CH}_{4}$ emission values simulated in this study are sim- ilar to that reported by Jain et al. (2000) and Adhya et al. (2000) for Indian rice fields. However, emissions were smaller (20-40 $\mathrm{kg} \mathrm{ha}^{-1}$ ) compared to that reported from many other countries such as Philippines (100-150 $\left.\mathrm{kg} \mathrm{ha}^{-1}\right)$ (Corton et al., 2000) and Japan (150-200 kg ha-1) (Yagi et al., 1996). Lower $\mathrm{CH}_{4}$ emission from Indian rice paddies compared to that of other countries could be due to 1) lower soil organic $\mathrm{C}$ status, 2) high percolation rate of sandy loam soils, which allows to leach substantial amount of DOC to lower soil profiles, 3 ) lower yield of rice with smaller rhizodeposition and 4) limited amount of organic residue recycling in soil.

Daily emission pattern of $\mathrm{CH}_{4}$ revealed that emission was recorded only during the period of flooding (Fig. 2). Flux of $\mathrm{CH}_{4}$ varied between 0 to $3.62 \mathrm{~kg} \mathrm{C} \mathrm{ha}^{-1} \mathrm{~d}^{-1}$. Continuous flooding emitted more $\mathrm{CH}_{4}$ than the midseason drainage and application of FYM enhanced the emission.

Daily emission of $\mathrm{N}_{2} \mathrm{O}$ showed that there were several peaks of fluxes (Fig. 3). Emission of $\mathrm{N}_{2} \mathrm{O}-\mathrm{N}$ ranged from 0 to $112.3 \mathrm{~g} \mathrm{ha}^{-1} \mathrm{~d}^{-1}$ during the year. Initial high peak of $\mathrm{N}_{2} \mathrm{O}$ emission was due to nitrification of ammonium-N present in soil. Subsequent peaks corresponded to fertilizer application events, which supplied substrate $\left(\mathrm{NH}_{4}^{+}\right)$for nitrification and $\mathrm{NO}_{3}^{-}$for subsequent denitrification.

\subsection{Upscaling of GHG emission from Indian rice fields}

\subsubsection{Database of soil and rice ecosystems}

The spatial distribution of SOC, clay contents, $\mathrm{pH}$ and bulk density of soils in different rice growing regions of India at the district scale are presented in Fig. 4. Being in the tropical region, the SOC contents of soil is low varying from $<0.2 \%$ to $1 \%$, with majority of soils containing $\mathrm{SOC}<0.6 \%$ (Fig. 4a). Clay contents of soil varied between 10 to $67 \%$. The soils of north India are lighter in texture while those of 

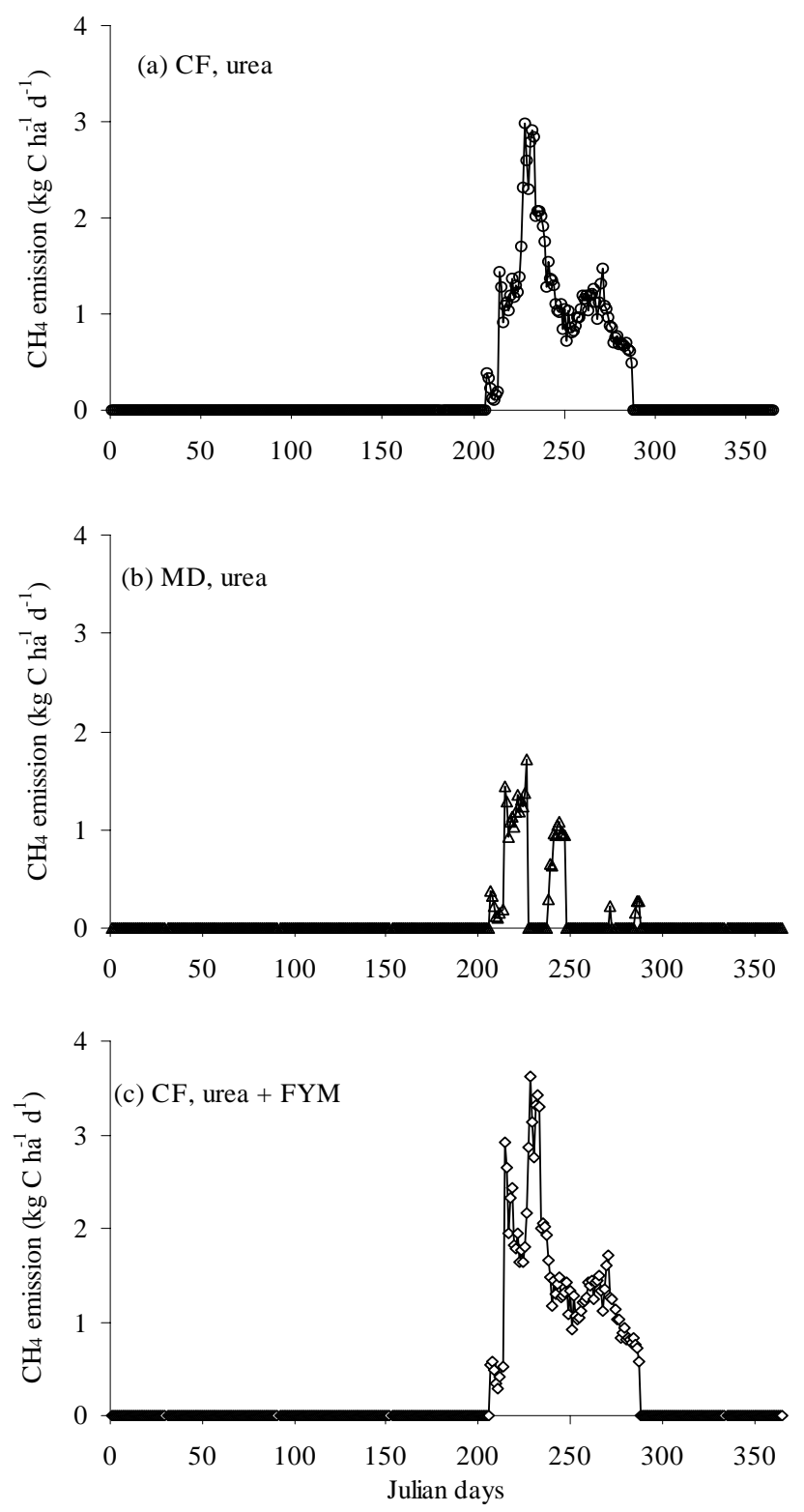

Fig. 2. Effect of continuous flooding (CF), midseason drainage (MD) and farmyard manure (FYM) on simulated methane emission.

central and west India are heavier (Fig. 4b). The majority of soils in India are alkaline in $\mathrm{pH}(\mathrm{pH}>7.5)$ while soils in eastern India are acidic to neutral in reaction (Fig. 4c). The soils of north India have higher bulk density as compared to those from the rest of the country (Fig. 4d).

There are mainly four major rice ecosystems in India (1) irrigated lowland, (2) rainfed lowland, (3) rainfed upland and (4) deepwater covering an area of 42.25 million ha (Table 3 ). Half of the area (21.41 million ha) is under irrigated lowland and 14.45 million ha is under rainfed lowland rice ecosystems. Upland rice is grown in $4.25 \mathrm{M}$ ha of land while deepwater rice occupies an area of 2.22 million ha. In lowland
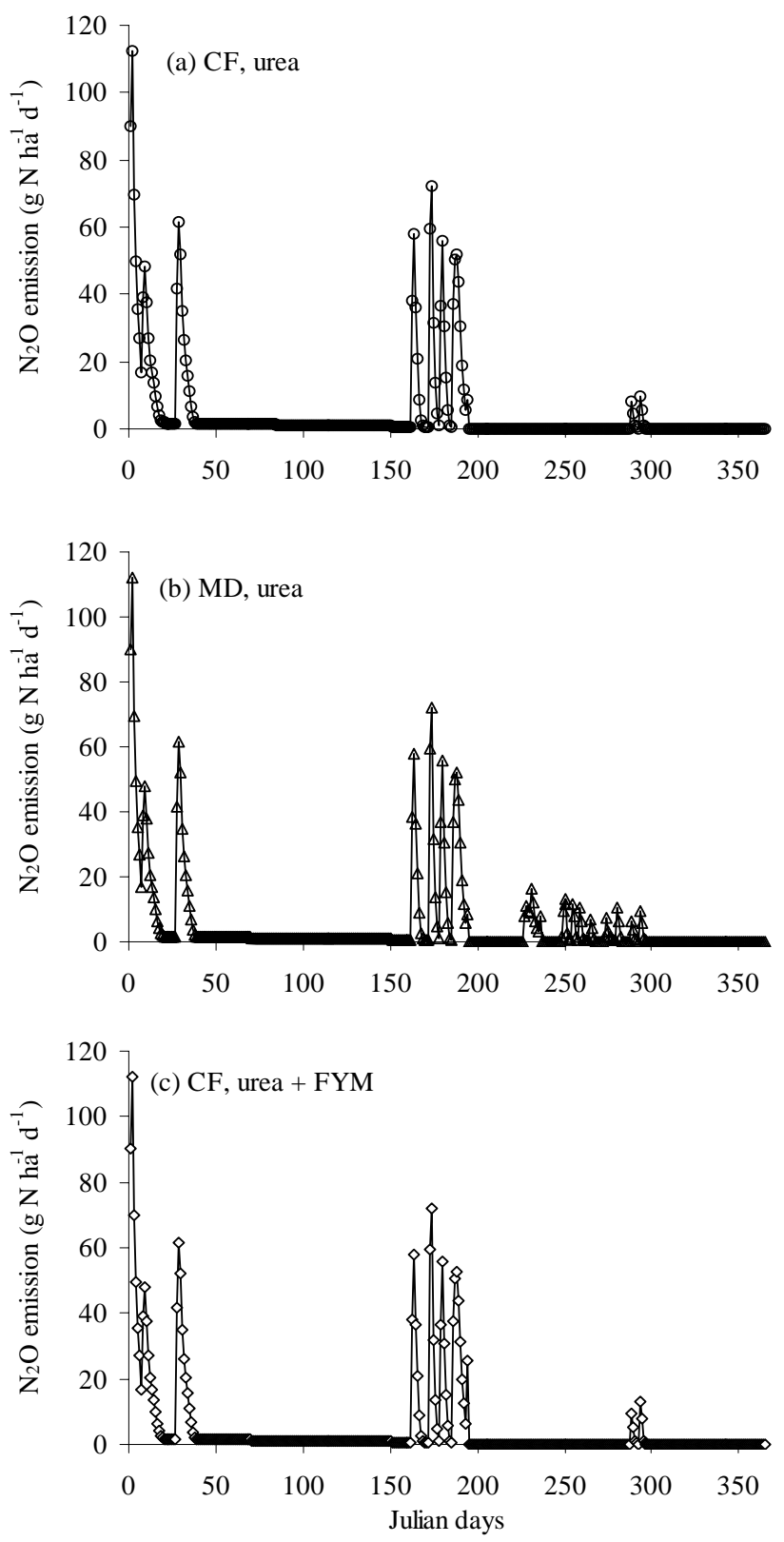

Fig. 3. Effect of continuous flooding (CF), midseason drainage (MD) and farmyard manure (FYM) on simulated nitrous oxide emission.

ecosystems rice seedlings are transplanted in puddled condition and the fields are kept either in continuous submergence or intermittently flooded depending on soil texture, rainfall and availability of irrigation water. Lowland rice fields in north India are generally intermittently flooded while those from east and south India are flooded continuously. In the case of upland rice the seeds are directly sown on pulverized seedbed and fields are never flooded. Deepwater rice is grown in low-lying high rainfall areas, where fields are inundated with water. In these areas rice is either direct seeded or transplanted depending upon the onset of monsoon. 
Table 3. Areas under the various rice ecosystems in different states of India.

\begin{tabular}{|c|c|c|c|c|c|}
\hline \multirow[t]{2}{*}{ State } & \multicolumn{5}{|c|}{ Area (million ha) } \\
\hline & $\begin{array}{l}\text { Irrigated } \\
\text { lowland }\end{array}$ & $\begin{array}{l}\text { Rainfed } \\
\text { lowland }\end{array}$ & $\begin{array}{l}\text { Rainfed } \\
\text { upland }\end{array}$ & Deepwater & Total \\
\hline Andhra Pradesh & 3.45 & & & 0.07 & 3.52 \\
\hline Arunachal Pradesh & 0.04 & 0.08 & & & 0.12 \\
\hline Assam & 0.53 & 1.60 & 0.22 & 0.10 & 2.45 \\
\hline Bihar & 1.93 & 1.59 & 0.53 & 0.67 & 4.72 \\
\hline Goa & 0.01 & 0.09 & & & 0.10 \\
\hline Gujarat & 0.40 & 0.22 & & & 0.62 \\
\hline Haryana & 0.79 & & & & 0.79 \\
\hline Himachal Pradesh & 0.05 & & 0.03 & & 0.08 \\
\hline Jammu and Kashmir & 0.25 & & 0.02 & & 0.27 \\
\hline Karnataka & 0.87 & 0.04 & 0.39 & & 1.30 \\
\hline Kerala & 0.27 & 0.08 & 0.15 & & 0.50 \\
\hline Maharashtra & 0.42 & & 0.79 & 0.32 & 1.53 \\
\hline Manipur & 0.08 & 0.09 & & & 0.17 \\
\hline Meghalaya & 0.05 & 0.06 & & & 0.11 \\
\hline Mizoram & 0.01 & 0.06 & & & 0.07 \\
\hline Madhya Pradesh & 1.23 & 3.82 & & & 5.05 \\
\hline Nagaland & 0.06 & 0.07 & & & 0.13 \\
\hline Orissa & 1.61 & 2.00 & 0.69 & 0.15 & 4.45 \\
\hline Pondicherry & 0.03 & & & & 0.03 \\
\hline Punjab & 2.24 & 0.03 & & & 2.27 \\
\hline Rajasthan & 0.05 & 0.11 & & & 0.16 \\
\hline Sikkim & 0.02 & & & & 0.02 \\
\hline Tamil Nadu & 2.06 & 0.27 & & & 2.33 \\
\hline Tripura & 0.05 & 0.21 & & & 0.26 \\
\hline Uttar Pradesh & 3.37 & 1.33 & 0.50 & 0.23 & 5.43 \\
\hline West Bengal & 1.53 & 2.68 & 0.88 & 0.68 & 5.77 \\
\hline Total & 21.41 & 14.45 & 4.20 & 2.22 & 42.25 \\
\hline
\end{tabular}

\subsubsection{Scaling up GHG emission}

The modeled results indicated that total $\mathrm{CH}_{4}$ flux from the simulated 42.25 million ha of rice in India ranged from 1.07 to $1.10 \mathrm{Tg} \mathrm{C}$ per year under continuous flooding conditions (Table 4). Earlier several attempts have been made to estimate $\mathrm{CH}_{4}$ emission from Indian rice fields (Mitra, 1991; Parashar et al., 1991; 1996; Matthews et al., 2000; Yan et al., 2003; Bhatia et al., 2004). However, only a few studies (Cao et al., 1996; Matthews et al., 2000c) have attempted to calculate detailed regional $\mathrm{CH}_{4}$ emissions using simulation modelling. The emission estimates vary greatly with the methodology adopted and assumptions made on the importance of different factors affecting $\mathrm{CH}_{4}$ emission (Table 5). Ahuja (1990) gave an estimate of $37.8 \mathrm{Tg} \mathrm{yr}^{-1} \mathrm{CH}_{4}$ emission from Indian paddies, which was based on emission data of European and American paddy fields and extrapolated to the Indian region. Later on a value of $3.0 \mathrm{Tg} \mathrm{yr}^{-1}$ was estimated on the basis of measurements done up to 1990 at various rice growing regions in the country (Mitra, 1991; Parashar et al., 1991). Parashar et al. (1996) fur- ther revised the budget to be $4.0 \mathrm{Tg} \mathrm{yr}^{-1}$ with a range between 2.7 to $5.4 \mathrm{Tg} \mathrm{yr}^{-1}$. Gupta et al. (2002) using average emission factors for all paddy water regimes, which included harvested areas having soils with high organic carbon and organic amendments, estimated a budget of $5.0 \mathrm{Tg} \mathrm{yr}^{-1}$. Recently, Yan et al. (2003) using region specific emission factors estimated India's $\mathrm{CH}_{4}$ emission to be $5.9, \mathrm{Tg} \mathrm{yr}^{-1}$. Matthews et al. (2000c) used the MERES model to simulate $\mathrm{CH}_{4}$ emission from rice paddies in India and estimated $2.1 \mathrm{Tg} \mathrm{CH}_{4} \mathrm{yr}^{-1}$. The present estimate of $1.5 \mathrm{Tg}$ is lower than the previous estimates, but is comparable with that of Sinha (1995), who estimated $1.2 \mathrm{Tg} \mathrm{CH}_{4} \mathrm{yr}^{-1}$ and Matthews et al. (2000c). However, Matthews et al. (2000c) assumed the percolation rate in soil to be zero due to the lack of spatial information on this parameter, and thus obtained higher emission estimate compared to the present study. In DNDC the percolation rate is calculated by the model using the soil parameters, given as inputs of the model.

With the intermittent flooding scenario, the national $\mathrm{CH}_{4}$ flux from rice fields was reduced to $0.12-0.13 \mathrm{Tg} C$ per year implying that the water management change in India dras- 
Table 4. Annual GHG emissions from Indian rice fields under continuous flooding and midseason drainage practices.

\begin{tabular}{|c|c|c|c|c|}
\hline \multirow[t]{2}{*}{ Parameter } & \multicolumn{2}{|c|}{ Continuous flooding } & \multicolumn{2}{|c|}{ Midseason drainage } \\
\hline & ${ }^{a}$ Minimum & ${ }^{b}$ Maximum & Minimum & Maximum \\
\hline $\mathrm{CH}_{4}$ emission $\left(\mathrm{Tg} \mathrm{C} \mathrm{yr}^{-1}\right)$ & 1.07 & 1.10 & 0.12 & 0.13 \\
\hline $\mathrm{N}_{2} \mathrm{O}$ emission $\left(\mathrm{Tg} \mathrm{N} \mathrm{yr}^{-1}\right)$ & 0.05 & 0.04 & 0.06 & 0.05 \\
\hline $\mathrm{CO}_{2}$ emission $\left(\mathrm{Tg} \mathrm{C} \mathrm{yr}^{-1}\right)$ & 21.16 & 60.96 & 16.66 & 48.80 \\
\hline GWP $\left(\mathrm{Tg} \mathrm{CO}_{2}\right.$ equiv. $\left.\mathrm{yr}^{-1}\right)$ & 130.93 & 272.83 & 91.73 & 211.80 \\
\hline
\end{tabular}

${ }^{a}$ Scenarios for minimum emission: Minimum of SOC, $\mathrm{pH}$ and bulk density and maximum of clay content of soil.

${ }^{b}$ Scenarios for maximum emission: Maximum of SOC, $\mathrm{pH}$ and bulk density and minimum of clay content of soil.

Table 5. Comparison of annual $\mathrm{CH}_{4}$ emission estimates from rice fields in India.

\begin{tabular}{|c|c|c|}
\hline Reference & $\begin{array}{l}\text { Estimate } \\
\left(\mathrm{Tg} \mathrm{CH}_{4} \mathrm{yr}^{-1}\right)\end{array}$ & Methodology used \\
\hline Ahuja (1990) & 37.5 & Extrapolated from studies in USA and Europe to the rice growing regions in India \\
\hline Mitra (1991) & 3.0 & Extrapolated from a limited No. of field measurements in India \\
\hline Matthews et al. (1991) & 21.7 & Based on area under rice, crop calendar and daily $\mathrm{CH}_{4}$ emission rate \\
\hline Taylor et al. (1991) & 18.4 & Assuming a $\mathrm{CH}_{4}-\mathrm{NPP}$ ratio of $5 \%$ \\
\hline Parashar et al. (1996) & 4.0 & Extrapolated from several measurements all over India \\
\hline Cao et al. (1996) & 14.4 & Using the Methane Emission Model (MEM) \\
\hline Sass and Fischer (1997) & 4.2 & Extrapolated from measured data from selected rice-growing areas in India \\
\hline ALGAS (1998) & 3.6 & Extrapolated from large No. of measurements all over India \\
\hline Matthews et al. (2000c) & 2.1 & Using the MERES simulation model \\
\hline This study & 1.5 & Using the validated DNDC model and newly compiled soil, rice area and weather data base \\
\hline
\end{tabular}

tically reduced $\mathrm{CH}_{4}$ fluxes. The intermittent flooding approach has been applied in many Asian countries such as India (Jain et al., 2000; Adhya et al., 2000), Philippines (Corton et al., 2000), China (Li et al., 2002), and Japan (Yagi et al., 1996) to reduce $\mathrm{CH}_{4}$ emissions.

With continuous flooding $\mathrm{N}_{2} \mathrm{O}$ emission ranged from 0.04 to $0.05 \mathrm{Tg} \mathrm{N} \mathrm{yr}^{-1}$ (Table 4). Shifting the water management from continuous flooding to intermittent flooding increased $\mathrm{N}_{2} \mathrm{O}$ fluxes to $0.05-0.06 \mathrm{Tg} \mathrm{N} \mathrm{yr}^{-1}$. But like $\mathrm{CH}_{4}$ emission, emission of $\mathrm{CO}_{2}$ reduced with intermittent flooding. The upscaling study for India, thus, revealed the complexity of GHG mitigation. When $\mathrm{CH}_{4}$ and $\mathrm{CO}_{2}$ emissions were reduced due to intermittent flooding, $\mathrm{N}_{2} \mathrm{O}$ emission increased. Since $\mathrm{N}_{2} \mathrm{O}$ possesses higher GWP, the increased $\mathrm{N}_{2} \mathrm{O}$ offset the benefit gained by decreasing $\mathrm{CH}_{4}$ and $\mathrm{CO}_{2}$ fluxes. However, total GWP of rice growing areas decreased from 130.93-272.83 $\mathrm{Tg} \mathrm{CO}_{2} \mathrm{yr}^{-1}$ with continuous flooding to $91.73-211.80 \mathrm{Tg}$
$\mathrm{CO}_{2} \mathrm{yr}^{-1}$ with intermittent flooding. The study on regional $\mathrm{N}_{2} \mathrm{O}$ emission from India is limited. Bhatia et al. (2004) estimated an emission of $0.08 \mathrm{Tg} \mathrm{N}_{2} \mathrm{O}-\mathrm{N} \mathrm{yr}{ }^{-1}$ while IINC (2004) estimated the value to be $0.15 \mathrm{Tg} \mathrm{N}_{2} \mathrm{O}-\mathrm{N} \mathrm{yr}{ }^{-1}$ using the IPCC methodology from all agricultural land (149 million ha) of the country.

The simulated spatial distribution of GHG emissions from Indian rice fields and their GWP under continuous flooding condition is shown in Fig. 5. Emission of $\mathrm{CH}_{4}$ ranged from $<10 \mathrm{~kg} \mathrm{CH}_{4}-\mathrm{C} \mathrm{ha}^{-1}$ to $>70 \mathrm{~kg} \mathrm{CH}_{4}-\mathrm{C} \mathrm{ha}^{-1}$ (Fig. 5a). The maximum emission value was $106 \mathrm{~kg} \mathrm{CH}_{4}-\mathrm{C} \mathrm{ha}^{-1}$. High emission values in some of the districts in north-west India could be due to high temperature $\left(>40^{\circ} \mathrm{C}\right)$ in the region during the rice growing season. Regions in the eastern India also showed higher emission because of high temperature and high SOC content compared to those from western part of the country. 

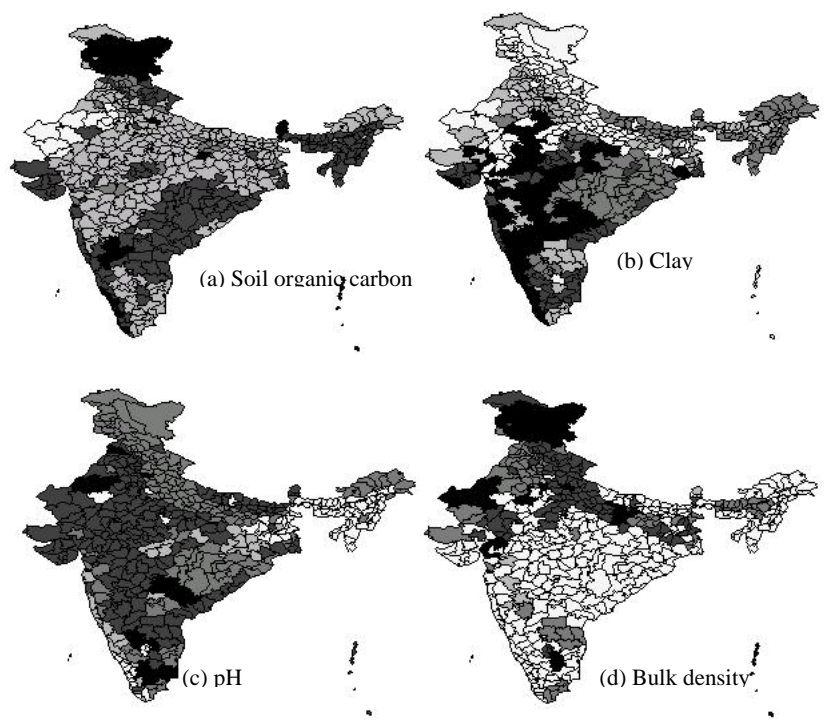

\begin{tabular}{|c|cccc}
\hline \multicolumn{1}{l}{ Legend } & $\begin{array}{c}\text { (a) Soil organic } \\
\mathrm{C}(\%)\end{array}$ & $\begin{array}{c}\text { (b) Clay } \\
(\%)\end{array}$ & \begin{tabular}{c} 
(c) $\mathrm{pH}$ \\
\multicolumn{1}{c|}{}
\end{tabular} & $\begin{array}{c}\text { (d) Bulk density } \\
\left(\mathrm{Mg} \mathrm{m}^{-3}\right)\end{array}$ \\
\hline & 0.2 & $<20$ & $<5.5$ & $<1.35$ \\
& $0.2-0.4$ & $20-30$ & $5.5-6.5$ & $1.35-1.40$ \\
& $0.4-0.6$ & $30-40$ & $6.5-7.5$ & $1.40-1.45$ \\
& $0.6-0.8$ & $40-50$ & $7.5-8.5$ & $1.45-1.50$ \\
& $>0.8$ & $>50$ & $>8.5$ & $>1.50$ \\
\hline
\end{tabular}

Fig. 4. Spatial distribution of organic carbon, clay contents, $\mathrm{pH}$ and bulk density of soils of India. Legends of the figures are given below.

Emission of $\mathrm{N}_{2} \mathrm{O}$ from the various rice ecosystems of India ranged from $<0.5 \mathrm{~g} \mathrm{~N}_{2} \mathrm{O}-\mathrm{N} \mathrm{ha}^{-1}$ to $>2.0 \mathrm{~g} \mathrm{~N}_{2} \mathrm{O}-\mathrm{N} \mathrm{ha}^{-1}$ (Fig. 5b) while emission of $\mathrm{CO}_{2}$ varied between $<600$ to $>2400 \mathrm{~kg} \mathrm{CO}_{2}-\mathrm{C} \mathrm{ha}^{-1}$ (Fig. 5c) under continuous flooding condition. Unlike $\mathrm{CH}_{4}$, emissions of $\mathrm{N}_{2} \mathrm{O}$ were higher from the south-western regions of the country while the regions in the eastern and south eastern India showed higher $\mathrm{CO}_{2}$ emission, similar to that of $\mathrm{CH}_{4}$ because of high temperature and high SOC content in these regions. The northern, eastern and southern parts of the country showed higher GWP (Fig. d), mainly because of higher $\mathrm{CH}_{4}$ and $\mathrm{CO}_{2}$ emissions. The GWP of the rice growing regions through out the country was $<2000$ to $>8000 \mathrm{~kg} \mathrm{CO}_{2}$ equivalent per year.

\section{Conclusions}

The DNDC model was generally able to encapsulate the major impacts of water management and various $\mathrm{N}$ fertilizer rates on rice crop performance and GHG emissions in tropical soils. The analysis suggested that the model can be applied for studying the GHG related issues in rice cropping systems of India. A trade-off between $\mathrm{CH}_{4}$ and $\mathrm{CO}_{2}$ emissions and $\mathrm{N}_{2} \mathrm{O}$ emission was determined. The tradeoffs that exist between the $\mathrm{CH}_{4}, \mathrm{CO}_{2}$ and $\mathrm{N}_{2} \mathrm{O}$ mitigation mea-
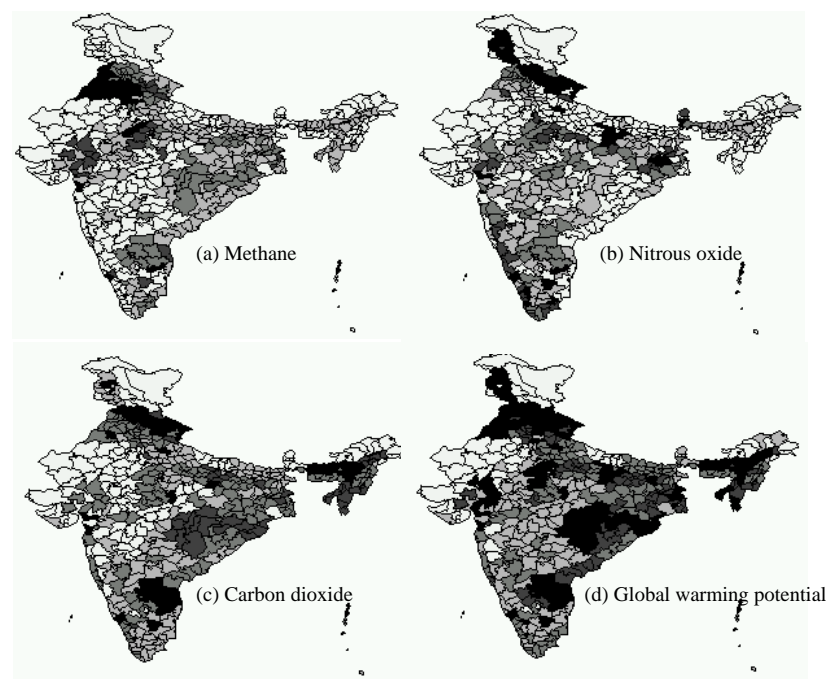

\begin{tabular}{|c|c|c|c|c|}
\hline Legend & $\begin{array}{c}\text { (a) } \mathrm{CH}_{4} \\
\left(\mathrm{~kg} \mathrm{CH} \mathrm{CH}_{4}-\mathrm{Cha}^{-1}\right)\end{array}$ & $\begin{array}{c}\text { (b) } \mathrm{N}_{2} \mathrm{O} \\
\left(\mathrm{kg} \mathrm{N}_{2} \mathrm{O}-\mathrm{N} \mathrm{ha}^{-1}\right)\end{array}$ & $\begin{array}{c}\text { (c) } \mathrm{CO}_{2} \\
\left(\mathrm{~kg} \mathrm{CO}_{2}-\mathrm{C} \mathrm{ha}{ }^{-1}\right)\end{array}$ & $\begin{array}{c}\text { (d) GWP } \\
\left(\mathrm{kg} \mathrm{CO}_{2} \text { equiv. ha }{ }^{-1}\right)\end{array}$ \\
\hline & $<10$ & $<0.5$ & $<600$ & $<2000$ \\
\hline & $10-30$ & $0.5-1.0$ & $600-1200$ & $2000-4000$ \\
\hline & $30-50$ & $1.0-1.5$ & $1200-1800$ & $4000-6000$ \\
\hline & $50-70$ & $1.5-2.0$ & $1800-2400$ & $6000-8000$ \\
\hline & $>70$ & $>2.0$ & $>2400$ & $>8000$ \\
\hline
\end{tabular}

Fig. 5. Annual emissions of methane, nitrous oxide, carbon dioxide and global warming potential of rice systems of India under continuous flooding condition. Legends of the figures are given below.

sures demonstrated the challenge of mitigating GHG emissions when focusing on the biogeochemical cycles in terrestrial ecosystems. Therefore, new tools for land-use analysis and planning are needed to reconcile the legitimate aims of improving water and $\mathrm{N}$ management and reducing GHG emission from agricultural fields. Models such as DNDC should be very useful to accelerate the application of available knowledge at field, farm and regional levels for optimizing agronomic management, quantifying changes in SOC and GHG emissions with changing land use, and developing mitigation options for GHG emissions.

There are uncertainties in estimation of GHG emissions from Indian rice fields because of its diverse soil and climate conditions and socio-economic status of the farmers. Moreover, various crop management practices, water and fertilizer management for example, play a major role in the emission. What is Indian agriculture's real contribution to GHG emissions can only be answered using simulation models. This will not only improve estimates of emissions and related impact assessments, but also provide a baseline from which future emission trajectories may be developed to identify and evaluate mitigation strategies.

Acknowledgements. The first author is thankful to the Alexander von Humboldt Foundation, Germany for providing a fellowship and the Forschungszentrum Karlsruhe, Institut für Meteorologie und 
Klimaforschung (IMK-IFU), Garmisch-Partenkirchen, Germany for providing facilities to carry out the work. C. Li's study was supported by NASA Terrestrial Ecology Program through project NAG5-12838.

Edited by: F. X. Meixner

\section{References}

Adhya, T. K., Bharati, K., Mohanty, S.R., Ramakrishnan, B., Rao, V.R., Sethunathan, N., and Wassmann, R.: Methane emission from rice fields at Cuttack, India, Nutr. Cycl. Agroecosyst., 58, 95-105, 2000.

Aggarwal, P. K., Kalra, N., Chander, S., and Pathak, H.: InfoCrop: A Generic Simulation Model For Annual Crops in Tropical Environments, Indian Agricultural Research Institute, New Delhi, 132, 2004.

Ahuja, D. R.: Estimating Regional Anthropogenic Emissions of Greenhouse Gases, US-EPA Climate Change Technical Series, Washington DC, 20, 1990.

ALGAS, Asia Least-cost Greenhouse gas Abatement Strategy: National Report on Asia Least Cost Greenhouse Gas Abatement Strategy (ALGAS), Ministry of Environment and Forest, Government of India, New Delhi, 1998.

Anastasi, C., Dowding, M., and Simpson, V.J.: Future $\mathrm{CH}_{4}$ emission from rice production, J Geophys Res., 97, 7521-7525, 1992.

Aulakh, M. S., Doran, J. W., and Mosier, A. R.: Soil denitrification - significance, measurement, and effects of management, Adv. Soil Sci. 18, 2-42, 1992.

Bachelet, D. and Neue, H.U.: Methane emissions from wetland rice areas of Asia, Chemosphere, 26, 219-237, 1993.

Battle, M., Bender, M., Sowers, T., Tans, P. P., Butler, J. H., Elkins, J. W., Ellis, J. T., Conway, T., Zhang, N., Lang, P., and Clarke, A. D.: Atmospheric gas concentrations over the past century measured in air from fin at the south pole, Nature, 383, 231-235, 1996.

Bhatia, A., Pathak, H., and Aggarwal, P. K.: Inventory of methane and nitrous oxide emissions from agricultural soils of India and their global warming potential, Curr. Sci., 87, 3, 317-324, 2004.

Brown, L., Syed, B., Jarvis, S. C., Sneath, R. W., Phillips, V. R., Goulding, K. W. T., and Li, C.: Development and application of a mechanistic model to estimate emission of nitrous oxide from UK agriculture, Atmos. Environ., 36, 917-928, 2002.

Butterbach-Bahl, K., Kesik, M., Miehle, P., Papen, H., and Li, C.: Quantifying the regional source strength of N-trace gases across agricultural and forest ecosystems with process based models, Plant Soil, 260, 311-329, 2004.

Cai, Z., Sawamoto, T., Li, C., Kang, G., Boonjawat, J., Mosier, A., Wassmann, R., and Tsuruta, H.: Field validation of the DNDC model for greenhouse gas emissions in East Asian cropping systems, Global Biogeochem. Cycles, 17, 4, 1107, doi:10.1029/2003GB002046, 2003.

Cao, M., Dent, J. B., and Heal, O. W.: Modelling methane emissions from rice paddies, Global Biogeochem. Cycles, 9, 183195, 1995.

Cao, M., Gregson, K., Marshall, S., Dent, J. B., and Heal, O.: Global methane emissions from rice paddies. Chemosphere, 55, 5, 879-897, 1996.
Corton, T. M., Bajita, J. B., Grospe, F. S., Pamplona, R. R., Asis Jr., C. A., Wassmann, R., Lantin, R. S., and Buendia, L. V.: Methane emission from irrigated and intensively managed rice fields in Central Luzon (Philippines), Nutr. Cycl. Agroecosyst., 58, 3753, 2000.

Duxbury, J. M., Bouldin, D. R., Terry, R. E., and Tate III, R. L.: Emissions of nitrous oxide from soils, Nature, 275, 602-604, 1982.

FAI (Fertilizer Association of India): Fertilizer Statistics (20002001), New Delhi, India, 2000.

FAO (Food and Agricultural Organization): FAO agricultural database (http://www.fao.org), FAO, Rome, Italy, 2000.

Gupta, Prabhat K., Sharma, C., Bhattacharya, S., and Mitra, A. P.: Scientific basis for establishing country greenhouse gas estimates for rice-based agriculture: An Indian case study, Nutr. Cycling Agroecosys., 64, 19-31, 2002.

Huang, Y., Sass, R. L., and Fisher Jr., F. M.: A semi-empirical model of methane emission from flooded rice paddy soils, Global Change Biol., 4, 3, 247-268, 1998.

IINC: India's Initial National Communication to the United Nations Framework Convention on Climate Change, Ministry of Environment and Forests, Government of India, 392, 2004.

Jain, M. C., Kumar, S., Wassmann, R., Mitra, S., Singh, S. D., Singh, J. P., Singh, R., Yadav, A. K., and Gupta, S.: Methane emissions from irrigated rice fields in northern India (New Delhi), Nutr. Cycl. Agroecosyst., 58, 75-83, 2000.

Kern, J. S., Gong, Z., Zhang, G., Zhuo, H., and Luo, G.: Spatial analysis of methane emissions from paddy soils in China and the potential for emissions reduction, Nutr. Cycl. Agroecosyst., 49, 181-195, 1997.

Khalil, M. A. K. and Shearer, M. J.: Methane emissions from rice agriculture, cited in: Shearer, M. J. and Khalil, M. A. K. 1993, Rice agriculture: emissions. In: Atmospheric Methane: Sources, Sinks, and Role in Global Change, Berlin, Springer-Verlag, 113, 250-253, 1993.

Li, C., Frolking, S., and Harriss, R. C.: Modeling carbon biogeochemistry in agricultural soils, Global Biogeochem, Cycles, 8, 237-254, 1994.

Li, C., Frolking, S., Crocker, G. J., Grace, P. R., Klir, J., Korcdhens, M., and Poulton, P. R.: Simulating trends in soil organic carbon in long-term experiments using the DNDC model, Geoderma, 81, 45-60, 1997.

Li, C., Mosier, A., Wassmann, R., Cai, Z., Zheng, X., Huang, Y., Tsuruta, H., Boonjawat, J., and Lantin, R.: Modeling greenhouse gas emissions from rice-based production systems: Sensitivity and upscaling, Global Biogeochemical Cycles, 18, 1-19, 2004.

Li, C., Qiu, J., Frolking, S., Xiao, X., Salas, W., Moore III, B., Boles, S., Huang, Y., and Sass, R.: Reduced methane emissions from large-scale changes in water management in China's rice paddies during 1980-2000, Geophys. Res. Lett., 29, 20, doi:10.1029/2002GL015370, 2002.

Li, C.: Modeling trace gas emissions from agricultural ecosystems, Nutr. Cycl. Agroecosyst., 58, 259-276, 2000.

Lu, W. F., Chen, W., Duan, B.W., Guo, W. M., Lu, Y., Lantin, R. S., Wassmann, R., and Neue, H. U.: Methane emission and mitigation options in irrigated rice fields in southeast China, Nutr. Cycling Agroecosys. 58, 65-73, 2000.

Matthews, E., Fung, I., and Lerner, J.: Methane emission from rice cultivation: geographic and seasonal distribution of cultivated ar- 
eas and emissions. Global Biogeochem, Cycles 5, 3-24, 1991.

Matthews, R. B., Wassmann, R., and Arah, J.: Using a crop/soil simulation model and GIS techniques to assess methane emsissions from rice fields in Asia, I. Model development, Nutr. Cycling Agroecosyst., 58, 141-159, 2000a.

Matthews, R. B., Wassmann, R., Buendia, L. V., and Knox, J.: Using a crop/soil simulation model and GIS techniques to assess methane emissions from rice fields in Asia. II. Model validation and sensitivity analysis, Nutr. Cycling Agroecosyst., 58, 161177, 2000b.

Matthews, R. B., Wassmann, R., Knox, J., and Buendia, L. V.: Using a crop/soil simulation model and GIS techniques to assess methane emissions from rice fields in Asia. IV. Upscaling to national levels, Nutr. Cycling Agroecosyst., 58, 201-217, 2000c.

Mitra, A. P.: Global Change: Greenhouse Gas Emissions in India A Preliminary Report, No.1, PID, CSIR, 18-21, 1991.

NBSS and LUP: Benchmark Soils of India, National Bureau of Soil Survey and Land Use Planning, Nagpur, India, 398, 1998.

Neue, H. U., Becker-Heidmann, P., and Scharpenseel, H. W.: Organic matter dynamics, soil properties and cultural practices in rice lands and their relationship to methane production, in: Soils and the greenhouse effect, edited by: Bouwman, A. F., 457-466, Wiley, New York, 1990.

Parashar, D. C., Rai, J., Gupta, P. K., and Singh, N.: Parameters affecting methane emission from paddy fields, Indian J. Radio Space Phys., 20, 12-17, 1991.

Parashar, D. C., Mitra, A. P., Gupta, Prabhat K., Rai, J., Sharma, R. C., Singh, N., Kaul, S., Lal, G., Chaudhary, A., Ray, H. S., Das, S. N., Parida, K. M., Rao, S. B., Swamy, S. P., Singh, G., Gupta, S. K., Singh, A. R., Banerjee, R., Sethunathan, N., Adhya, T. K., Rao, V. R., Palit, P., Saha, A. K., Purkait, N. N., Chaturvedi, G. S., Sen, S. P., Sen, M., Sarkar, B., Banik, A., Subbaraya, B. H., Lal, S., Venkatramani, S., and Sinha, S. K.: Methane budget from paddy fields in India, Chemosphere, 33, 4, 737-757, 1996.

Parton, W. J.: The CENTURY model, in: Evaluation of soil organic matter models using existing long-term datasets, edited by: Powlson, D. S., Smith, P., and Smith, J. U., NATO ASI Series I, 38, 283-293, 1996.

Pathak, H., Bhatia, A., Shiv Prasad, Singh, S., Kumar, S., Jain, M. C., and Kumar, U.: Emission of nitrous oxide from soil in ricewheat systems of Indo-Gangetic plains of India, Environ. Monitoring Assessment, 77, 2, 163-178, 2002.

Pathak, H., Prasad, S., Bhatia, A., Singh, S., Kumar, S., Singh, J., and Jain, M. C.: Methane emission from rice-wheat cropping system of India in relation to irrigation, farmyard manure and dicyandiamide application, Agric. Ecosys. Environ., 97, 309-316, 2003.
Rodhe, A. L.: A comparison of the contribution of various gases to the greenhouse effect, Science, 248, 1217-1219, 1990.

Sass, R. L. and Fisher, F. M.: Methane emissions from rice paddies: a process study summary, Nutr. Cycling Agroecosyst., 49, 119$127,1997$.

Sinha, S. K.: Methane emission from rice paddies: excellent methodology but poor extrapolation, Curr. Sci., 68, 643-646, 1995.

Smith, W. N., Desjardins, R. L., Grant, B., Li, C., Lemke, R., Rochette, P., Corre, M. D., and Pennock, D.: Testing the DNDC model using $\mathrm{N}_{2} \mathrm{O}$ emissions at two experimental sites in Canada, Canada J. Soil Sci., 82, 365-374, 2002.

Smith, W. N., Grant, B., Desjardins, R. L., Lemke, R., and Li, C.: Estimates of the interannual variations of $\mathrm{N}_{2} \mathrm{O}$ emissions from agricultural soils in Canada, Nutr. Cycling Agroecosyst., 68, 37 45, 2004.

Stange, F., Butterbach-Bahl, K., Papen, H., ZechmeisterBoltenstern, S., Li, C., and Aber, J.: A process-oriented model of $\mathrm{N}_{2} \mathrm{O}$ and $\mathrm{NO}$ emission from forest soils 2, Sensitivity analysis and validation, J. Geophys. Res., 105, 4385-4398, 2000.

Taylor, J. A., Brasseur, G. P., Zimmerman, P. R., and Cicerone, R. J.: A study of the sources and sinks of methane and methyl chloroform using a global three-dimensional Lagrangian tropospheric tracer transport model, J. Geophys. Chem., 96, 3013-3044, 1991.

Velayutham, M. and Bhattacharya, T.: Soil Resource Management, in: Natural Resource management for agricultural production in Indiam International conference on managing natural resources for sustainable agricultural production in the 21st century, 14-18 February, 2000, New Delhi, India, 2000.

Watson, R. T., Zinyowera, M. C., Moss, R. H., and Dokken, D. J.: Climate Change 1995, impacts, adaptations and mitigation of climate change: Scientific-technical analyses, Intergovernmental Panel on Climate Change, Cambridge University Press, USA, 879, 1996.

Yadav, R. L. and Subba Rao, A. V. M.: Atlas of Cropping Systems in India. PDCSR Bulletin No. 2001-02, 96 Project Directorate for Cropping Systems Research. Modipuram, Meerut 250110 , India, 2001.

Yagi, K., Tsuruta, H., Kanda, K., and Manami, K.: Effect of water management on methane emission from a Japanese rice field: Automated methane monitoring, Global Biogeochem. Cycles, 10, 255-267, 1996.

Yan, X., Ohara, T., and Akimoto, H.: Development of region specific emission factors and estimation of methane emission from rice fields in the East, Southeast and South Asian countries, Global Change Biol., 9, 1-18, 2003. 